\title{
PERBEDAAN JUMLAH BAKTERI TRAKHEA PADA TINDAKAN ORAL HYGIENE MENGGUNAKAN CHLORHEXIDINE DAN POVIDONE IODINE PADA PENDERITA DENGAN VENTILATOR MEKANIK
}

\author{
Fitri Hapsari Dewi*, Jati Listiyanto Pujo**, Ery Leksana** \\ * Bagian Anestesiologi dan Terapi Intensif RSUD dr. Moewardi/ FK UNS Surakarta \\ ** Bagian Anestesiologi dan Terapi Intensif RSUP dr. Kariadi / FK UNDIP Semarang
}

\begin{abstract}
Background: pneumonia is a nosocomial infection that often occurs. Pneumonia can be caused by bacterial colonization in the trachea due to aspiration of upper respiratory tract bacteria. Oral hygiene in the upper respiratory tract can decrease the number of bacteria.
\end{abstract}

Objective: To find the differences in decrease in the number of tracheal bacteria with oral hygiene chlorhexidine $0.2 \%$ and povidone iodine $1 \%$ on patients with mechanical ventilator.

Methods: A randomized clinical control trial study on 30 patients with mechanical ventilator. Patients were divided into 2 groups $(n=15)$, group 1 using chlorhexidine $0.2 \%$ and group 2 using povidone iodine 1\%. Each group was given oral hygiene every 12 hours for 48 hours. Each group was taken of tracheal secretions before and after treatment, for later examination counting the number and types of bacteria. Statistics using the Wilcoxon test and Mann-Whitney test (with degrees of significance $<0.05$ ).

Results: This study found a decrease the number of bacteria trachea in chlorhexidine group $78.99 \pm 69.105$ (significant difference $p=0.04$ ) more than in the povidone iodine group $24.91 \pm 104.764$ (not significantly different $p=0.75$ ). While the comparative difference in the two groups of test results obtained $p=0144$ (not significantly different).

Conclusion: The decrease in the number of tracheal bacteria on oral hygiene with chlorhexidine $0.2 \%$ was not different from povidone iodine $1 \%$

Keywords: chlorhexidine $0.2 \%$, povidone iodine $1 \%$, the number of tracheal bacteria, oral hygiene, mechanical ventilator.

\begin{abstract}
ABSTRAK
Latar belakang: Pneumonia merupakan infeksi nosokomial yang sering terjadi. Pneumonia dapat disebabkan karena kolonisasi bakteri di trakhea karena aspirasi bakteri saluran nafas atas. Tindakan oral hygiene pada saluran nafas atas dapat menurunkan jumlah bakteri.

Tujuan: Untuk mengetahui adanya perbedaan penurunan jumlah bakteri trakhea pada tindakan oral hygiene dengan chlorhexidine $0,2 \%$ dan povidone iodine $1 \%$ pada penderita dengan ventilator mekanik.

Metode: Merupakan penelitian randomized clinical control trial pada 30 penderita dengan ventilator mekanik. Penderita dibagi menjadi 2 kelompok $(n=15)$, kelompok 1 menggunakan chlorhexidine $0,2 \%$ dan kelompok 2 menggunakan povidone iodine $1 \%$. Masing -masing kelompok diberikan oral hygiene tiap 12 jam selama 48 jam. Tiap kelompok diambil sekret dari trakhea sebelum dan setelah perlakuan, untuk kemudian dilakukan
\end{abstract}


pemeriksaan hitung jumlah dan jenis bakteri. Uji statistik menggunakan Wilcoxon dan Mann-Whitney test ( dengan derajat kemaknaan $<0,05$ ).

Hasil: Pada penelitian ini didapatkan penurunan jumlah bakteri trakhea pada kelompok chlorhexidine sebesar 78,99 $\pm 69,105$ ( berbeda bermakna $p=0,04$ ) lebih banyak bila dibandingkan pada kelompok povidone iodine 24,91 $\pm 104,764$ ( berbeda tidak bermakna $\mathrm{p}=0,75$ ). Sedangkan pada uji selisih komparatif dua kelompok didapatkan hasil berbeda tidak bermakna $(\mathrm{p}=0.144)$.

Simpulan: Penurunan jumlah bakteri trakhea pada tindakan oral hygiene dengan chlorhexidine $0,2 \%$ tidak berbeda bermakna dengan povidone iodine $1 \%$

Kata kunci: chlorhexidine 0,2\%, povidone iodine 1\%, jumlah bakteri trakhea, oral hygiene, ventilator mekanik.

\section{PENDAHULUAN}

Infeksi nosokomial merupakan salah satu penyebab morbiditas dan mortalitas di rumah sakit. ${ }^{1}$ Infeksi nosokomial yang disebabkan oleh pneumonia bakteri disebabkan karena adanya kolonisasi bakteri di trakhea. Pneumonia bakteri karena infeksi nosokomial yang terjadi setelah dua hari pemakaian ventilator mekanik disebut dengan pneumonia terkait ventilator/ventilator associated pneumonia (VAP), kejadian ini merupakan infeksi nosokomial yang sering didapatkan di ICU. $^{2}$

Pasien yang terintubasi memiliki kemungkinan mengalami pneumonia lebih tinggi $21 \%$ dibandingkan dengan yang tidak mendapatkan saluran nafas buatan. ${ }^{3}$ Pneumonia yang didapat di rumah sakit merupakan penyakit infeksi saluran nafas bawah yang didahului dengan adanya jumlah bakteri atau infeksi saluran nafas atas. Aspirasi bakteri dari saluran pencernaan atas merupakan penyebab penting terjadinya kolonisasi bakteri di trakhea. ${ }^{4}$

Pneumonia yang didapat di rumah sakit diawali dengan adanya aspirasi makro atau mikro dari sekret terinfeksi yang berasal dari saluran nafas atas. Berbagai organisme ini kemudian dapat memperbanyak jalan masuk dan kemudian membentuk jumlah bakteri seperti biofilm yang secara cepat dapat melapisi permukaan bagian dalam dari pipa trakhea. Hal ini seringkali diikuti dengan jumlah bakteri organisme patogen di trakhea. $^{5}$

Pembersihan sekret di saluran nafas atau higienitas saluran nafas merupakan proses fisiologis normal yang diperlukan untuk menjaga patensi saluran nafas dan mencegah terjadinya infeksi saluran nafas. Oleh karena itu, perawatan pasien - pasien yang terintubasi meliputi pengisapan trakhea untuk mempermudah pembuangan hasil - hasil sekresi saluran nafas. ${ }^{5}$

Dekontaminasi oral dapat dilakukan dengan antiseptik oral seperti chlorhexidine glukonat atau povidone iodine. ${ }^{6,7}$ Chlorhexidine glukonat dapat menurunkan tingkat kejadian pneumonia nosokomial pada pasien - pasien dengan sakit kritis. Penggunaan chlorhexidine glukonat secara bilasan oral sebanyak dua kali sehari dapat menurunkan tingkat kejadian infeksi saluran nafas sebesar $69 \% .^{5}$

Faktor resiko kejadian pneumonia adalah jumlah bakteri pada orofaring oleh bakteri patogen potensial seperti Staphylococcus aureus, Streptococcus pneumonia atau bakteri gram negatif. ${ }^{8,9,10}$ Trakhea dan 
selang endotrakhea secara cepat menjadi tempat jumlah bakteri pada pasien dengan sakit kritis, kultur dari sputum atau aspirasi trakhea merupakan cara yang dapat digunakan untuk mengetahui jumlah dan jenis mikroorganismenya. ${ }^{5}$

Tujuan dari penelitian ini adalah untuk mengetahui adakah perbedaan jumlah bakteri trachea pada tindakan oral hygiene menggunakan chlorhexidine $0,2 \%$ bila dibandingkan dengan povidone iodine $1 \%$ yang diberikan pada penderita dengan ventilator mekanik.

\section{METODE}

Penelitian ini merupakan penelitian dengan bentuk rancangan randomized clinical control trial. Pengukuran dilakukan pada awal dan akhir perlakuan. Kelompok 1 chlorhexidine 0,2\% sebagai oral hygiene pada penderita dengan ventilator mekanik. Kelompok 2 povidone iodine $1 \%$ sebagai oral hygiene pada penderita dengan ventilator mekanik di ICU RSUP Dr. Kariadi Semarang pada bulan Februari hingga April 2011. Peneliti tidak mengetahui penderita karena urutan penderita berdasarkan undian terhadap 2 kelompok secara acak.

Kriteria inklusi yaitu pasien dewasa dengan ventilator mekanik. Kriteria eksklusi meliputi alergi atau terdapat kontraindikasi terhadap obat yang digunakan, keganasan, mengidap HIV, dan penggunaan kortikosteroid dalam jangka lama. Penelitan ini menggunakan sampel 15 orang untuk masing-masing kelompok, sehingga total sampel adalah 30. Keluarga penderita diberikan penjelasan tentang hal-hal yang akan dilakukan, serta bersedia untuk mengikuti penelitian dan mengisi formulir informed consent.

Pada kelompok 1 diberikan chlorhexidine $0,2 \%$ sebanyak $25 \mathrm{ml}$ setiap 12 jam. Pada kelompok 2 diberikan povidone iodine 1\% sebanyak $25 \mathrm{ml}$ setiap 12 jam. Hasil kultur sekret trakhea dihitung jumlah bakteri setelah 48 jam dengan 4 kali perlakuan.

Hasil analisis disajikan dalam bentuk grafik Box Plot. Analisis analitik akan dilakukan untuk menguji hasil kultur mikrobiologi pada kedua kelompok perlakuan dengan uji non parametrik Mann Whitney,Wilcoxon. Semua uji analitik menggunakan $\alpha=0,05$. Semua perhitungan statistik menggunakan perangkat lunak Statitiscal Package for Social Science (SPSS) 15.

\section{HASIL}

Telah dilakukan penelitian pada 30 pasien yang memenuhi kriteria inklusi dan ekslusi tertentu. Penderita dibagi menjadi dua kelompok, yaitu kelompok (1) chlorhexidine yang mendapatkan chlorhexidine 0,2\% dan kelompok (2) povidone iodine yang mendapatkan povidone iodine 1\%, kedua kelompok diberikan oral hygiene tiap 12 jam selama 48 jam. Karakteristik subyek penelitian ditampilkan pada Tabel 1.

Uji normalitas Shapiro-Wilk digambarkan pada tabel di atas, dimana karakteristik umum umur pada kelompok chlorhexidine memiliki distribusi yang normal $(p>$ 0,05), sedangkan kelompok povidone iodine memiliki distribusi tidak normal ( $p$ $<0,05)$ sehingga untuk uji homogenitas diperlukan Mann Whitney $U$ test. Karakteristik jenis kelamin dengan skala nominal digunakan uji kai-kuadrat $\left(\mathrm{x}^{2}\right)$. Hasilnya didapatkan data homogen $(p>$ $0,05)$ dari semua variabel.

Jumlah bakteri trakhea yang diambil sebelum dan sesudah mendapat perlakuan pada masing-masing kelompok subyek penelitian ditampilkan dalam Tabel 2.

Berdasarkan uji normalitas data sebagaimana terlihat pada Tabel 3, jumlah bakteri trakhea pada pemberian 
Tabel 1. Karakteristik Umum Subyek Penelitian

\begin{tabular}{llllc}
\hline No & Variabel & Chlorhexidine & Povidone iodine & $p$ \\
\hline 1. & Umur & $49,47 \pm 16,128$ & $48,20 \pm 13,718$ & $0,917^{*}$ \\
\hline 2. & Jenis kelamin & $15(26,7-23,3)$ & $15(23,3-26,7)$ & $0,133^{* *}$ \\
\hline
\end{tabular}

Tabel 2. Jumlah bakteri trakhea masing-masing kelompok

\begin{tabular}{lcccc}
\hline \multirow{2}{*}{ Variabel } & \multicolumn{2}{c}{ Chlorhexidine 0,2\% } & \multicolumn{2}{c}{ Povidone iodine 1\% } \\
\cline { 2 - 5 } & Pre $($ mean $\pm S D)$ & Post (mean $\pm S D)$ & Pre (mean $\pm S D)$ & $\begin{array}{c}\text { Post } \\
(\text { mean } \pm S D)\end{array}$ \\
\hline $\begin{array}{l}\text { Jumlah } \\
\text { bakteri }\end{array}$ & $198.827 \pm 121.192$ & $119.833 \pm 113.915$ & $206.767 \pm 123.021$ & $\begin{array}{c}181.853 \pm 107.0 \\
38\end{array}$ \\
\hline
\end{tabular}

Tabel 3. Uji normalitas masing-masing kelompok

\begin{tabular}{lcccc}
\hline \multirow{2}{*}{ Variabel } & \multicolumn{3}{c}{ P } \\
\cline { 2 - 5 } & \multicolumn{2}{c}{ Chlorhexidine 0,2\% } & Povidone Iodine 1\% \\
\cline { 2 - 5 } & Pre & Post & Pre & Post \\
\hline Jumlah Bakteri & 0,002 & 0,014 & 0,001 & 0,068 \\
\hline
\end{tabular}

Tabel 4. Uji pre dan post masing-masing kelompok

\begin{tabular}{lcc}
\hline & Chlorhexidine 0,2\% & Povidone iodine 1\% \\
\hline Pre & $198.827 \pm 121.192$ & $206.767 \pm 123.021$ \\
\hline Post & $119.833 \pm 113.915$ & $181.853 \pm 107.038$ \\
\hline $\boldsymbol{p}$ & 0,004 & 0,75 \\
\hline
\end{tabular}


chlorhexidine $0,2 \%$ maupun povidone iodine $1 \%$ didapatkan distribusi tidak normal $(p<0,05)$, maka untuk masingmasing kelompok penelitian digunakan Wilcoxon Signed Rank Test. Hasil analisis masing-masing kelompok disajikan dalam Tabel 4.

Tabel 4 menunjukkan jumlah bakteri trakhea pada kelompok chlorhexidine $0,2 \%$ sebelum perlakuan $198.827 \pm 121.192$ dan setelah perlakuan119.833 \pm 113.915 yang berarti mengalami penurunan sebesar $78,99 \pm 69,105$. Pada kelompok povidone iodine $1 \%$ jumlah bakteri trakhea sebelum perlakuan $206.767 \pm 123.021$ dan setelah perlakuan $181.853 \pm 107.038$ yang berarti mengalami penurunan sebesar $24,91 \pm 104,764$.

Hasil uji statistik yang dilakukan dengan menggunakan Wilcoxon Signed Rank Test, perubahan jumlah bakteri trakhea pada kelompok chlorhexidine menunjukkan perubahan yang bermakna $(p<0,05)$. Sedangkan jumlah bakteri trakhea pada kelompok povidone iodine menunjukkan perbedaan yang tidak bermakna $(p>0,05)$.
Pada analisis komparatif antar kelompok digunakan Mann Whitney U-test. Hasil analisis disajikan dalam boxplot Grafik 1.Pada analisis komparatif antar kelompok, didapatkan penurunan jumlah bakteri trakhea pada kelompok chlorhexidine $\quad 0,2 \%$ dibandingkan kelompok povidone iodine $1 \%$ dengan perbedaan tidak bermakna $(p>0,05)$.

\section{PEMBAHASAN}

Antiseptik atau antimikroba pada dosis terapi, seperti chlorhexidine dan colistin, dapat menjadi alternatif untuk dekontaminasi orofaring. Chlorhexidine memiliki spektrum luas untuk mikroorganisme gram positif dan mikroorganisme gram negatif. ${ }^{6}$

Penggunaan chlorhexidine glukonat $0,12 \%$ secara bilasan oral sebanyak dua kali sehari dapat menurunkan tingkat kejadian infeksi saluran nafas sebesar $69 \%$ dan menurunkan penggunaan antibiotik sebesar $43 \%$ tanpa mempengaruhi pola resistensi antibiotik. Pengaruh terbesar

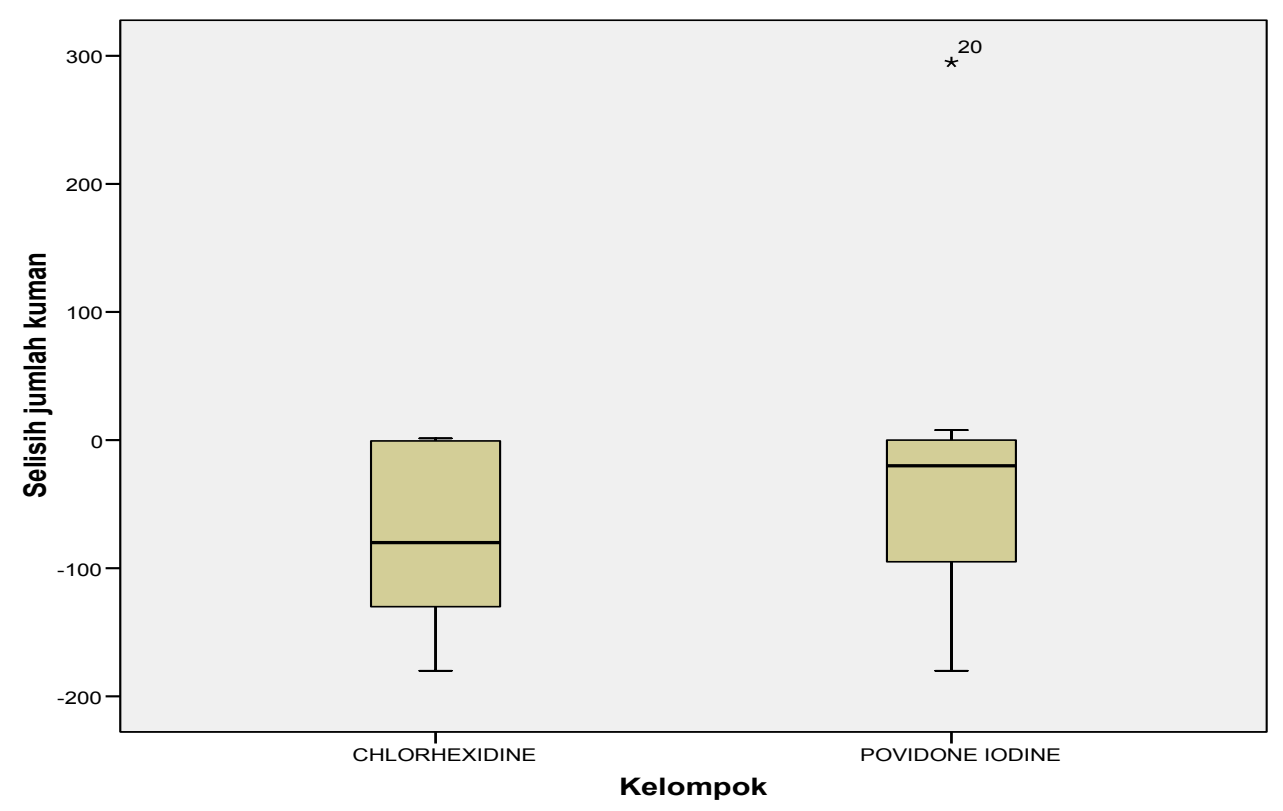

Grafik 1. Perbandingan jumlah bakteri trakhea dari kedua kelompok perlakuan 
didapatkan pada pasien - pasien yang telah diintubasi selama lebih dari 24 jam dimana pasien - pasien ini memiliki derajat jumlah bakteri bakteri terbesar. ${ }^{5,}$

Penelitian Rahn, dikatakan bahwa povidone iodine dapat menurunkan angka kejadian bakterimia pada pasien dengan resiko tinggi infeksi dengan memberikan cairan povidone iodine secara rutin pada sulkus ginggiva.

Penelitian yang dilakukan ini adalah membandingkan jumlah kuman antara pemberian oral hygiene chloerhexidine $0,2 \%$ dengan povidone iodine $1 \%$ pada penderita dengan ventilator mekanik. Sebelumnya belum pernah ada yang membandingkan antara keduanya terhadap jumlah bakteri trakhea. Pada hasil penelitian ini digunakan 30 subyek penelitian dengan karakteristik yang telah diseleksi melalui kriteria inklusi dan eksklusi didapatkan 30 penderita dengan karakteristik umur, jenis kelamin yang tidak berbeda bermakna $(\mathrm{p}>0,05)$ sehingga layak dibandingkan.

Hasil analisis uji Wilcoxon pada kedua kelompok secara terpisah menunjukkan bahwa jumlah bakteri trakhea sebelum dan sesudah perlakuan berbeda bermakna pada kelompok chlorhexidine $(\mathrm{p}=0,004)$ dan tidak berbeda bermakna pada kelompok povidone iodine $(\mathrm{p}=0,075)$. Sedangkan selisih jumlah bakteri trakhea antara kedua kelompok dianalisis dengan uji komparatif Mann-Whitney, dengan hasil menunjukkan tidak berbeda bermakna $(p=0,144)$.

Kelompok chlorhexidine menunjukkan penurunan jumlah bakteri bermakna secara statistik. Hasil ini sesuai dengan penelitian Mirelle Koeman yang menyatakan bahwa terdapat penurunan jumlah kolonisasi di trakhea pada penderita dengan ventilator mekanik yang diberi chlorhexidine selama 48 jam perlakuan. ${ }^{6}$
Kelompok povidone iodine menunjukkan penurunan jumlah bakteri tidak bermakna secara statistik. Penelitian ini sesuai dengan penelitian Joel Chua, yang meneliti povidone iodine $1 \%$ yang diberikan terhadap penderita dengan ventilator mekanik terhadap angka kejadian VAP yang dinilai secara klinis bermakna tetapi tidak bermakna secara statistik $^{11}$.

Meskipun didapatkan hasil tidak berbeda bermakna pada uji komparatif kedua kelompok, akan tetapi chlorhexidine lebih efektif menurunkan jumlah bakteri trakhea dibanding dengan povidone iodine. Hal ini dilihat dari penurunan jumlah bakteri trakhea sebelum dan sesudah perlakuan pada kelompok chlorhexidine sebesar $78,99 \pm 69,105(\mathrm{p}=0,004)$, sedangkan pada kelompok povidone iodine sebesar 24,91 $\pm 104,764(\mathrm{p}=0,075)$.

Lebih efektifnya chlorhexidine dalam menurunkan jumlah bakteri dibandingkan dengan povidone iodine mungkin disebabkan oleh sifat chlorhexidine yang memiliki broad spectrum yang luas, aktivitas antibakterinya lebih cepat, absorbsinya minimal, aktivitas dalam darah baik, dan memiliki efek residu.

Kekurangan pada penelitian ini adalah ketidakmampuan peneliti dalam mengontrol waktu antara pengambilan sampel di ICU, pengiriman, serta pemeriksaan sampel di laboratorium mikrobiologi klinik. Peneliti telah berusaha meminimalkan kekurangan dengan cara mempersingkat pengiriman serta langsung dilakukan pemeriksaan saat sampel diterima petugas.

\section{SIMPULAN}

Terdapat penurunan jumlah bakteri trakhea pada kelompok chlorhexidine secara bermakna, terdapat penurunan 
jumlah bakteri trakhea pada kelompok povidone iodine secara tidak bermakna, serta terdapat penurunan jumlah bakteri trakhea pada kelompok chlorhexidine dibandingkan kelompok povidone iodine secara tidak bermakna.

Sebaiknya chlorhexidine $0,2 \%$ digunakan sebagai oral hygiene terpilih pada penderita dengan ventilator mekanik dibandingkan povidone iodine $1 \%$.

\section{DAFTAR PUSTAKA}

1. Hunter JD. Ventilator associated pneumonia. Postgraduate medical journal 2006; 82 (965): 172-78. Available from : http// pmj.bmj.com/ content/82/965/172.full

2. Kohl BA, Hanson CW. Critical care protocols. In: Miller RD, editor. Miller's anesthesia $7^{\text {th }} \mathrm{ed}$. America: Elsevier, 2010;Vol 2:23-87.

3. Chan EY, Ruest A, Meade M, Cook DJ. Oral decontamination for prevention of pneumonia in mechanically ventilated adults: systematic review and meta-analysis. BMJ 2007;334:889. Available from : http//www.medscape.com/ viewarticle/707833 4

4. Wiryana M. Ventilator associated pneumonia. Jurnal penyakit dalam 2007 ; 8(3):254-69. Available from : http // ejournal.unud.ac.id/.../ ventilator\%20associated\%20pneumonia

5. Jelic S, Cunningham JA, Factor P. Clinical review:airway hygiene in the intensive care unit. Critical care 2008;12:209. Available from : http// www.ncbi.nlm.nih.gov > Journal

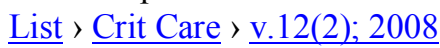

6. Koeman M, Hak F, Ramsay G, Joore, Kaasjager K, Hans, et al. Oral decontamination with chlorhexidine reduces the incidence of ventilator-associated pneumonia. American journal of respiratory and critical care medicine 2006; 173 : 1348-1355. Available from: http // ajrccm.atsjournals.org/cgi/content/ short $/ 173 / 12 / 1348$

7. Ogata J, Minami K, Miyamoto H, Horishita T, Ogawa M, Sata T, et al. Gargling with povidone -iodine reduces the transport of bacteria during oral intubation. Can j anaesth 2004;51(9):9326. Available from : http// pubget.com/ paper/15525622

8. Genuit T, Mccarter RJ, Roghman MC, Bochichio G, Napolitano LM. Prophylactic chlorhexidine oral rinse decrease ventilatorassociated pneumonia in surgical ICU patients. Surgical infection 2001;2:1-14. Available from:http// pubmed/12594876

9. Panchabhai TS, Dangayach NS, Khrisnan A, Kothari VM, Karnad DR.Oropharyngeal cleansing with $0,2 \%$ chlorhexidine for prevention of nosocomial pneumonia in critical care patients. Chest 2008;135:1116-1118. Available from:http// chestjournal.chestpubs.org/content/135/5/1150.

10. Morgan G E, Mikhail M S. Critical care. In :Morgan GE, ed. Clinical Anesthesiology.4th ed. Connecticut, Appleton and Lange; 2006.

11. Joel V, Chua MD, Eleanor A, Dominguez MD, Cherrie M, Sisson MD, et al. The efficacy of povidone-iodine oral rinse in preventing ventilator-associated pneumonia: A randomized double-blind, placebo-controlled (VAPOR) trial: preliminary report. J mikrobiol infect dis 2004;33(4):153-161. Available from : http // www.psmid.org.ph/vol33/ vol33num4topic153.pdf 